\title{
Journal of Urban
}

ISSN 2067-4082

e-ISSN 2068-9969

L-ISSN 2067-4082

\section{and}

\section{Regional Analysis}

Volume IX - Issue 2 - December, 2017

\section{CONTENTS}

Anthony SORENSEN, Michael SOFER (Guest Editors) - EDITORIAL FOREWORD

Adjie PAMUNGKAS - REARRANGEMENT OF ADMINISTRATIVE BOUNDARIES FOR REDUCING INNER-CITY DISPARITY: CASE STUDY OF TANJUNG PINANG CITY, INDONESIA

Sri Rum GIYARSIH, Muh Aris MARFAI-REGIONAL TRANSFORMATION IN SEMARANG CITY, INDONESIA

Jiři NOVOSÁK, Oldřich HÁJEK, Jana NOVOSÁKOVÁ, Milan LINDNER - ENTERPRISE SUPPORT POLICY AND TERRITORIAL COHESION: THE CZECH REPUBLIC (2007-2013)

Seong-Kyu HA, Ki-Hyun KWON - IN-MOVERS' HOUSING CHOICE AND GENTRIFICATION IN SEOUL

Olga GUROVA - THE MAIN TENDENCIES OF SOCIAL AND ECONOMIC TRANSFORMATION OF CITIES IN THE TRANS-BAIKAL TERRITORY

Kenichi SHIMAMOTO - COOPERATIVE GAME THEORY APPROACH TO ESTABLISHING A LANDSCAPE AGREEMENT

BOOK REVIEWS

www.jurareview.ro 


\title{
Journal of Urban and Regional Analysis
}

\section{Volume IX - Issue 2 - December, 2017}

\author{
Journal indexed in:
}

\section{SCOPUS}

EBSCO

CENTRAL \& EASTERN EUROPEAN ACADEMIC SOURCE DATABASE COVERAGE LIST

PROQUEST SCITECH JOURNALS

ULRICHSWEB

DIRECTORY OF OPEN ACCESS JOURNALS (DOAJ)

INDEX COPERNICUS INTERNATIONAL

KNOWLEDGE BASE SOCIAL SCIENCES EASTERN EUROPE (GESIS)

University of Bucharest 
Journal of Urban and Regional Analysis, vol. IX, 2, 2017, p.107

\section{CONTENTS}

- Anthony SORENSEN, Michael SOFER (Guest Editors) - Editorial Foreword

- $\quad$ Adjie PAMUNGKAS - Rearrangement of Administrative Boundaries for Reducing Inner-City Disparity: Case Study of Tanjung Pinang City, Indonesia

- $\quad$ Sri Rum GIYARSIH, Muh Aris MARFAI - Regional Transformation in Semarang City, Indonesia

- Jiří NOVOSÁK, Oldřich HÁJEK, Jana NOVOSÁKOVÁ, Milan LINDNER - Enterprise Support Policy and Territorial Cohesion: The Czech Republic (2007-2013)

- Seong-Kyu HA, Ki-Hyun KWON - In-Movers' Housing Choice and Gentrification in Seoul

- Olga GUROVA - The Main Tendencies of Social and Economic Transformation of Cities in the Trans-Baikal Territory

- Kenichi SHIMAMOTO - Cooperative Game Theory Approach to Establishing a Landscape Agreement

- Book Reviews 


\title{
THE MAIN TENDENCIES OF SOCIAL AND ECONOMIC TRANSFORMATION OF CITIES IN THE TRANS-BAIKAL TERRITORY
}

\author{
Olga GUROVA \\ Institute of Natural Resources, Ecology and Cryology, \\ Siberian Branch of the Russian Academy of Sciences, Russia
}

\begin{abstract}
In this paper, city-status settlements of the Trans-Baikal Territory are considered. The Trans-Baikal Territory is a territorial entity of the Russian Federation located in the south of Asian part of Russia. Cities of the Trans-Baikal Territory are economic and cultural centres of regions; they play an important role in development and support of the surrounding territory. In this paper, demographic, migration, social and economic conditions of the cities are reviewed. The analysis of conditions in cities has been performed on the basis of statistical data collected from the administrations of the cities of the region and other published statistical materials on the basis of a comparative geographical method, as well as a review of the literature. The generality of tendencies in the social and economic situation and regional peculiarities of cities are shown. In all cities of the region there is a decrease in the population. The paper concludes that, by now, the issue of migration loss is the strategically important development problem in the Trans-Baikal Territory.
\end{abstract}

Key Words: cities of the Trans-Baikal Territory, population dynamics, migration, social and economic transformation

\section{Introduction}

The geographical study of cities as an independent branch of socio-economic geography has its own history. Currently, scientists continue to study social, economic and ecological problems of urban development. Urban geography is one of the dynamically developing fields of geography aiming at solving the problems of urbanized regions and urban development. A city is studied as a complex system and the research includes the analysis of historical and geographical, social, economic and other aspects of the development of cities (Pertsik 2009).

The rapid development of cities in Russia in the twentieth century is associated with industrialization, the development of industrial functions of cities and an increase in the urban population. In the modern period of development of urban geography, in the scientific literature there are works devoted to such a phenomenon as the reduction of the population in cities generating problems of urban development. This theme is seen in the works of Russian (Karachurina and Mkrtchyan 2010, Rykov 2010, Antonov et al. 2014, Gunko 2014, Savoskul et al. 2014) and foreign authors (Pallagst et al. 2009, Avila de Sousa et al. 2011, Couch and Cocks 2011, Hollander 2011, Wiechmann and Pallagst 2012, Bański et al. 2016).

In order to denote the cities with decreasing population, the international research practice uses the term of "shrinking city". This term can be applied to a city which loses population because of economic decline. Similar trends of decreasing urban population are observed in some regions of economically developed countries - the USA, Great Britain, Germany and even China. China has even created a research network dedicated to the phenomenon of shrinking cities for studying this important issue (www.beijingcitylab.com/projects-1/15shrinking-cities). Two top-priority approaches have been worked out: in the USA (in 1950- 
1960) - it is based upon attempts to develop profitable branches of industry which are in demand in a city, the development of business and the creation of infrastructure; and in Germany (1990-2000) - switching to inner reserves, improvement of the quality of life and adaptation of a city to the population decrease (Efremova 2015).

Studies on the topic of shrinking cities were realized within several foreign projects, such as: "SHRINK SMART - The Governance of Shrinkage within a European Context (20092012)" (www.shrinksmart.eu). It is based on comparative case studies from seven urban regions throughout Europe. The project aims on analysing different trajectories of shrinkage, understanding the main challenges for urban planning and elaborating alternatives for urban governance. Also, the project "Cities Regrowing Smaller" is a network of more than 60 European researchers working on the topic of urban shrinkage in Europe. The result of the project was a map illustrating shrinkage in Europe (Avila de Sousa et al. 2011).

Several collective books were published on this topic (Pallagst et al. 2014, Richardson and Nam 2014). The last paper emphasized: "the urban shrinkage characterised by economic decline and population loss has been increasingly becoming a rather normal phenomenon of urban development worldwide" (Richardson and Nam 2014: 1). The book consists of 4 parts and it deals with a wide range of issues, dedicated to the topic of shrinking cities. The first part presents the analysis, classification and prospects of shrinking cities, the second part is devoted to different countries, and the third to individual cities. The fourth part of the book addresses the issue of environmental benefits (and costs) of shrinking cities (Richardson and Nam 2014).

There are several reasons of shrinkage (Schett 2011): economic changes (deindustrialization) (Manchester is an example), structural changes (suburbanization, outflow of population) (Detroit), political changes, and a combination of these causes (East Germany). In the paper of Großmann et al. (2013), the authors note that the morphological structure of the city, its ecology, and culture can also affect the diversity of urban trajectories. This can practically be observed in the cities of the Trans-Baikal Territory. For example, in the city of Baley, the deterioration in the environmental situation contributed to the migration of the population, but in Nerchinsk - which has a rich cultural heritage, the migration is small.

A large number of foreign works devoted to the phenomenon of urban shrinkage shows its global nature and it covers various issues related to the social and spatial consequences of population decline, urban planning and industrial decline of cities, and urban ecology with a decrease in the population (Herrmann et al. 2016).

In the Russian context, the "analysis of transforming small and medium-sized towns within the period of Russian economy transfer to the phase of market relations is of specific scientific merit. Approximately $85 \%$ of total quantity of cities in the country is represented by this category" (Medvedeva 2004: 3). The small and mid-sized cities, and the small urban settlements of the eastern regions of the country are of great importance for the social and economic development of these territories because of less density of population and of high geographic dispersion of cities in Siberia. The scientific concept of "center-periphery" spatial development implies that the economic development of territories and cities is going by different directions: the population is concentrated in the regional centers while the provincial territories (small towns, rural areas) lose population and suffer decline. Cities, as well as other inhabited localities, are affected by the negative processes of development described hereunder.

\section{Methodology}

The cities of the Trans-Baikal Territory represent the object of study. The main goal of the study was to identify the main trends of demographic and socio-economic development of 
cities in the Trans-Baikal Territory in the modern period. In the course of the study, the author carried out the selection of statistical information on the cities of the Trans-Baikal Territory. Surveys of representatives of local administrations of cities were conducted, and city development programs were studied. The statistical material was also analysed. For this purpose, the published official statistics were used. In addition, the author collected statistics directly from the administrations of the cities of the Trans-Baikal Territory.

The work used comparative-geographical, cartographic, and descriptive-analytical methods. For the purposes of the research, the predominant industry (manufacturing, mining) and the functional type (administrative, transport and other functions) was determined in all the cities of the region. This allows to better understand the importance of the city in the region.

To analyse the demographic situation in cities, an important indicator of it is the population dynamics. The natural increase in the population is the absolute value of the difference between the numbers of the born and the dead in a certain period of time. Its magnitude can be either positive or negative. A positive natural increase indicates an excess of fertility over mortality. The number is also affected by the migration of the population. The migration growth (loss) of the population represents the difference between those who arrived and those who left the territory. Thus, there were considered such statistical indicators of cities as: population, natural increase/decrease of population, migration growth/decline of population, the total area of housing stock, input in action of houses, improvement of housing city fund, the volume of industrial production and the availability of enterprises in cities.

General description of the cities of the Trans-Baikal Territory

Table 1

\begin{tabular}{|c|c|c|c|c|c|}
\hline & $\begin{array}{l}\text { Name of the } \\
\text { City }\end{array}$ & $\begin{array}{c}\text { The } \\
\text { City } \\
\text { Status } \\
\text { Earned } \\
\text { in } \\
\text { (year) }\end{array}$ & $\begin{array}{l}\text { Area } \\
\text { of the } \\
\text { Terri- } \\
\text { tory, } \\
\mathrm{km}^{2}\end{array}$ & $\begin{array}{l}\text { The Main Branches of } \\
\text { Industry }\end{array}$ & Functional Type \\
\hline 1 & Chita & 1851 & 534 & $\begin{array}{l}\text { Construction, power, } \\
\text { manufacturing industry, } \\
\text { mining }\end{array}$ & $\begin{array}{l}\text { Administrative, economic, } \\
\text { transportation centre, } \\
\text { railway station }\end{array}$ \\
\hline 2 & Borzya & 1950 & 187 & Manufacturing industry & $\begin{array}{c}\text { Transportation centre, } \\
\text { railway station }\end{array}$ \\
\hline 3 & Baley & 1938 & 48 & $\begin{array}{l}\text { Mining (gold mining), } \\
\text { manufacturing industry, }\end{array}$ & Industrial centre \\
\hline 4 & Nerchinsk & 1689 & 100 & Manufacturing industry & $\begin{array}{l}\text { Distribution, administrative } \\
\text { and cultural centre }\end{array}$ \\
\hline 5 & Sretensk & 1926 & 82 & Manufacturing industry & $\begin{array}{c}\text { Transportation centre, } \\
\text { railway station }\end{array}$ \\
\hline 6 & Krasnokamensk & 1969 & 428 & $\begin{array}{l}\text { Mining, manufacturing } \\
\text { industry }\end{array}$ & $\begin{array}{l}\text { Industrial and transportation } \\
\text { centre, railway station }\end{array}$ \\
\hline 7 & Shilka & 1951 & 105 & Manufacturing industry, & $\begin{array}{c}\text { Transportation centre, } \\
\text { railway station }\end{array}$ \\
\hline 8 & Mogocha & 1950 & 95 & Manufacturing industry & $\begin{array}{c}\text { Transportation centre, } \\
\text { railway station }\end{array}$ \\
\hline 9 & Khilok & 1951 & 170 & Manufacturing industry & $\begin{array}{c}\text { Transportation centre, } \\
\text { railway station }\end{array}$ \\
\hline 10 & $\begin{array}{l}\text { Petrovsk- } \\
\text { Zabaykalsky }\end{array}$ & 1926 & 300 & Manufacturing industry & $\begin{array}{c}\text { Transportation centre, } \\
\text { railway station }\end{array}$ \\
\hline
\end{tabular}

Source: Own research and Cities of the Russian Federation (goroda-oblosti.ru) 
There are 10 cities located in the Trans-Baikal Territory (Fig. 1, Table 1): Chita, Borzya, Baley, Nerchinsk, Sretensk, Shilka, Krasnokamensk, Mogocha, and Khilok. Chita is an administrative, economic, cultural and traffic centre of the Trans-Baikal Territory; it is located $6198 \mathrm{~km}$ from Moscow by railway. There are also new cities which emerged recently, such as Krasnokamensk, and historical cities such as Nerchinsk in the territory.

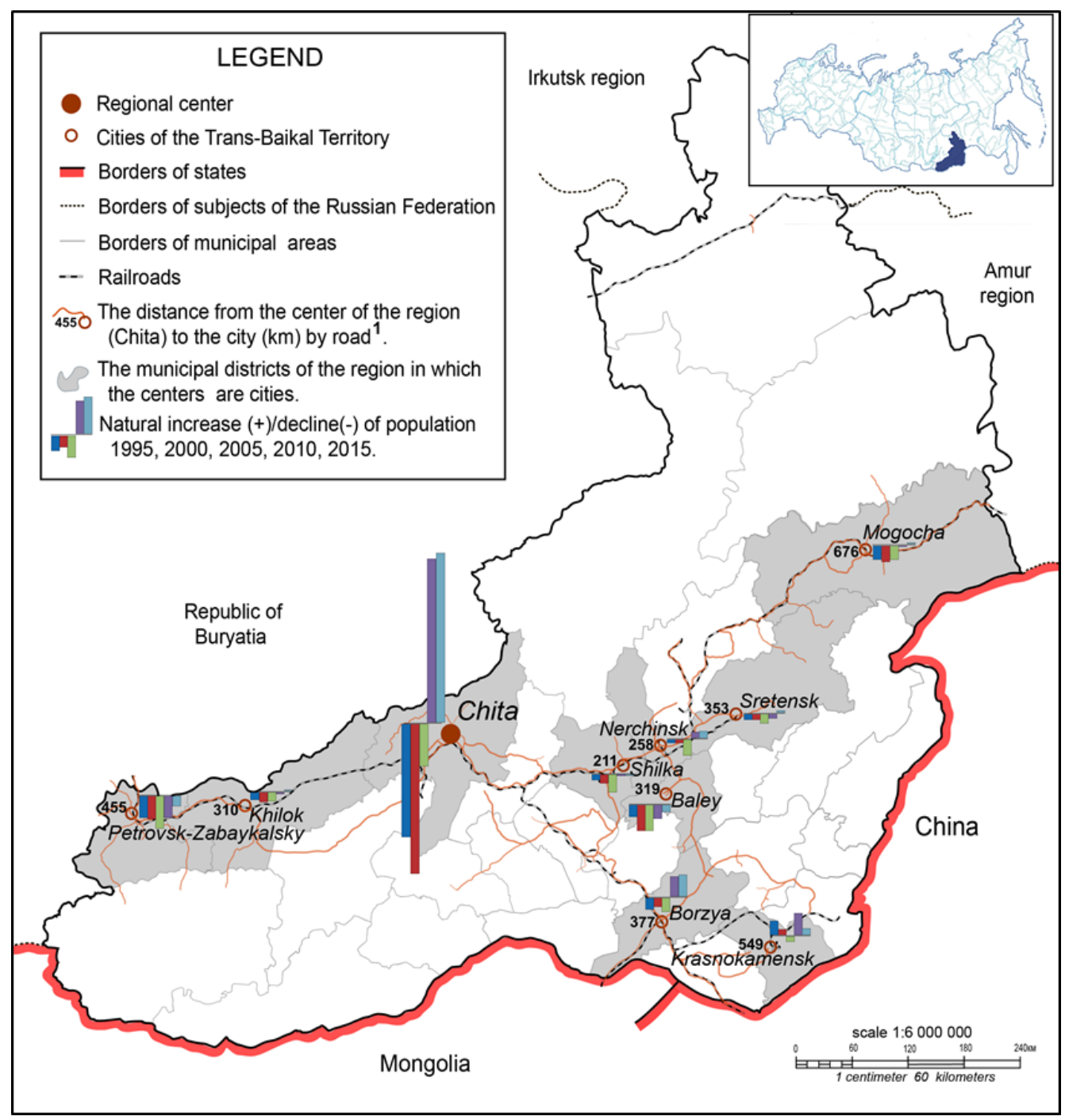

Fig. 1 - Cities of the Trans-Baikal Territory

On the map-sidebar: The Trans-Baikal Territory on the map of Russia

${ }^{1}$ According to the Atlas of Roads of the Trans-Baikal Territory (2011)

The territory development was initially determined by the interest towards its biological resources (fur) and its mineral resources afterwards. The migration of the Russian population 
into the areas of Cisbaikalia and Transbaikalia commenced in 1620-1630s; by the middle of the century, a network of Russian settlements - stockaded small towns and villages located along the main rivers - appeared. The Trans-Siberian Railway played the major role in the development; it was constructed at the end of the XIXth century - the beginning of the XX century; new cities were constructed along the railway (Preobrazhenskii 1965). Nerchinsk stockaded town was the most important economic, administrative, trade and diplomatic centre; by the end of the XVII century, it became an economically developed town (Konstantinova N. N. 2002). By the end of the XIX century, Chita became the largest town. In 1897, its population was of 11520 people (Konstantinova T. A. 2002).

In 1897, the population of Eastern Transbaikalia cities was of 19.8 thousand people, and 61.8 thousand people in 1917. Town settlements were mostly growing by means of migration of population from the western regions of the country. No considerable migration was observed from the Trans-Baikal villages to the cities; it played no important role in growth of cities (Vorobyev 1975).

In terms of population, only Krasnokamensk is a mid-sized city (from 50 to 100 thousand people); other ones are small cities (to 50000 people). The population of Khilok, Baley and Sretensk is less than 12000 people. Baley and Krasnokamensk are single-industry cities. Krasnokamensk is the newest and the second largest city of the territory. Other cities of the territory (except Nerchinsk) are referred to the category of transportation centres, serving as railway stations.

Borzya was founded in 1770. Later, during the construction of the Trans-Baikal Railway and the railway station, the further development of the village was predetermined by the favourable location for transportation among the areas specializing in agricultural production. In 1924, the population of Borzya village, located near the railway station, was of 2976 people (Solodova 2004), and then the town was further growing and it gradually became a transportation junction.

The city of Petrovsk-Zabaikalsky is the oldest metallurgical centre of Siberia. The city-forming enterprise in the city was the Petrovsk-Zabaikalsk Metallurgical Plant. Originally, it was called the Petrovsky Iron-Making Plant, built in 1789 and named after Peter I. In 1905, the ironmaking industry stopped, the production of cast iron, forging and mechanical handicrafts continued. In the late 1970s, the production declined. Marten's shop was working on imported iron and metal scrap. The shortage of raw materials and materials led to a decrease in output. In 1998, the average number of employees was of 1914 people. In 2001, the enterprise stopped its activity (Gatypova and Boltovskaya 2006).

The city of Mogocha was founded in 1908 as a railway station. At the beginning of the 20th century, railway enterprises (locomotive and wagon depots) were opened in the city, and an airport was built, which was profiled until the 1990s. The population grew: in 1917, the population of the city was of 1780 people, in 1922, of 3962 people (Gladun 2006). The city of Khilok was founded in 1895 as a railway station. Now, the population works at the enterprises of the railway, in municipal institutions, in the agricultural production, and in trade.

\section{Results}

\section{Demographic and migration conditions}

The whole region is characterized by a migration outflow: within the period from 2000 to 2015 , the population of the whole territory decreased by 82848 people. The population of all cities in the territory (except Chita) decreased by 62835 people from 1989 to 2015. By now, the population in some towns of the territory (such as Baley and Sretensk) reduced even more than generally in the region in comparison with 1989 (Table 2). 511094 people lived in all cities of 
the territory at the beginning of 2015 ; this makes $47 \%$ of the territory population; 117370 people live in the small towns of the territory $(10.7 \%)$.

The urban population as of January, $1^{\text {st }}$ (people), of the Trans-Baikal Territory

\begin{tabular}{|c|c|c|c|c|c|c|c|c|c|}
\hline \multirow[t]{2}{*}{ City } & \multicolumn{7}{|c|}{ Years } & \multirow{2}{*}{$\begin{array}{c}\text { Difference } \\
\text { between } \\
1989 \text { and } \\
2015\end{array}$} & \multirow{2}{*}{$\begin{array}{c}2015 \\
\text { against } \\
1989 \\
\%\end{array}$} \\
\hline & 1959 & 1979 & 1989 & 2002 & 2010 & 2012 & 2015 & & \\
\hline Chita & 171800 & 302600 & 362500 & 317183 & 323246 & 327400 & 339929 & -22571 & 93.7 \\
\hline $\begin{array}{l}\text { Petrovsk- } \\
\text { Zabaykalsky }\end{array}$ & 29800 & 30900 & 28200 & 21164 & 18786 & 18100 & 17144 & -11056 & 60.8 \\
\hline Borzya & 23700 & 35800 & 36600 & 31588 & 30685 & 30800 & 29405 & -7195 & 80.3 \\
\hline Baley & 28800 & 25900 & 23900 & 14797 & 12859 & 12200 & 11696 & -12204 & 49 \\
\hline Nerchinsk & 13500 & 16900 & 17300 & 15811 & 14025 & 14900 & 14746 & -2554 & 85.2 \\
\hline Sretensk & 15100 & 13400 & 10500 & 8258 & 7913 & 6700 & 6608 & -3892 & 63 \\
\hline $\begin{array}{l}\text { Krasnoka- } \\
\text { mensk }\end{array}$ & - & 51000 & 68200 & 58128 & 56987 & 55400 & 53795 & -14405 & 78.9 \\
\hline Shilka & 16800 & 17200 & 17500 & 15305 & 13947 & 13700 & 13162 & -4338 & 75.2 \\
\hline Mogocha & 14900 & 17700 & 18100 & 13788 & 13250 & 13400 & 13640 & -4460 & 75.3 \\
\hline Khilok & 15900 & 14200 & 13700 & 11344 & 11185 & 11400 & 10969 & -2731 & 80 \\
\hline $\begin{array}{l}\text { Trans-Baikal } \\
\text { Territory }\end{array}$ & 1036400 & 1233400 & 1375300 & 1155340 & 1108791 & 1099396 & 1087452 & -287848 & 79 \\
\hline
\end{tabular}

Source: Own research based on the data of the following statistical books - Social and Economic Performance of Municipal Districts and Urban Districts of the Trans-Baikal Territory $(2012,2015)$; Population of the Trans-Baikal Territory as of January $1^{\text {st }}(2010)$; Municipal Entities of the Trans-Baikal Territory (2015); $70^{\text {th }}$ Anniversary of Chita Region (2007); Demography of the Trans-Baikal Territory (2015).

It should be noted that the population in Chita significantly decreased by 2000 in comparison with 1990 (correspondingly it amounted to 307000 and 369651 people) (Chita Regional Committee on Statistics 1991, Chita Regional Committee on Statistics 2001), and this was caused by the economic decline. As reported (Bulayev and Kovalyova 2004), during the last decade of the XXth century, all regions of the country suffered a consistent decrease of population, in different proportions over time.

The recent increase of population in Chita is explained by the positive natural increase associated with the federal programs aimed at the stimulation of the birth rate and the recent positive migration balance. The positive natural increase in 2010 and 2015 was observed in Chita, Borzya, Nerchinsk and Krasnokamensk; population decline was observed in PetrovskZabaykalsky, Shilka, Mogocha, Baley (Fig. 2, Table 3).

In comparison with 1960s, Baley (former gold mining centre) and Sretensk lost half of their total population. In Petrovsk-Zabaykalsky, in 1970, the population level reached 32000 people (Bulayev and Baranova 2015). Baley and Petrovsk-Zabaykalsky, in the beginning of 2000s and earlier, have been already referred to extremely depressive territories (i.e. with the highest population decline); Borzya and Chita have been referred to the category of stagnation territories (Bulayev and Kovalyova 2004). The recent positive natural increase of Borzya and Krasnokamensk does not result in an increase of population because of sufficiently high migration loss. Whereas, according to Bulayev and Kovalyova (2004), the earlier absence of natural increase was compensated by the migration inflow. However, the negative migration balance is observed in all other cities of the territory (Table 3 ).

The highest migration loss was observed in Krasnokamensk, Borzya, Baley, and PetrovskZabaykalsky. In 2010, the migration loss exceeded the natural increase only in Krasnokamensk, while in 2015 - only in Chita. The migration outflow exceeds the natural increase only in Borzya (both in 2010 and in 2015). The migration outflow exceeds the natural decrease in Baley (both in 2010 and in 2015). In Nerchinsk, the natural increase is 
low, as well as the migration loss. In Shilka, both migration loss and natural population decline are low. Mogocha and Khilok are characterized by an extremely low natural increase at sufficiently high migration loss. The population of the territory is migrating to the centre (Chita) and moving outside the boundaries of the region. The employable population of Chita is also migrating to other regions, but the positive migration balance is mainly reached by the migrants from the CIS and China.

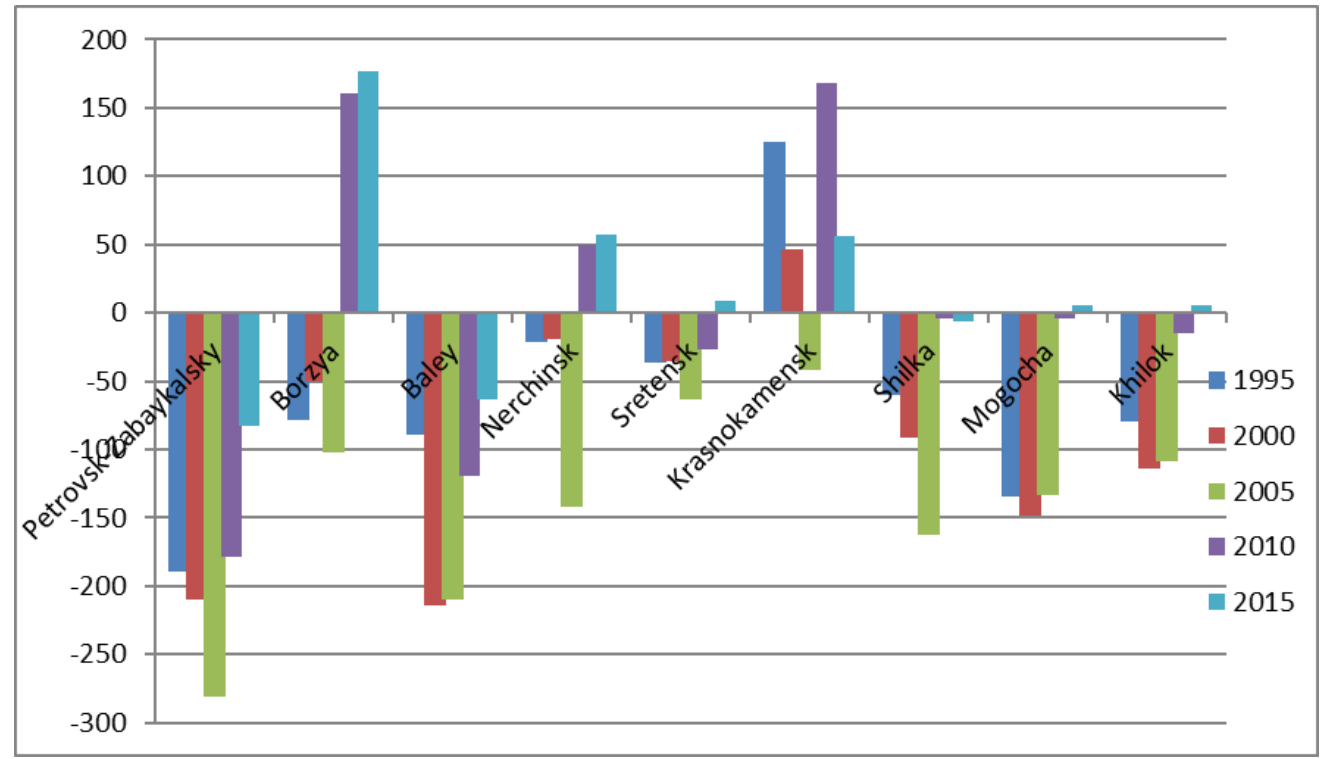

Fig. 2 - Natural increase of population in the cities of the Trans-Baikal Territory

Source: Own research based on the data of the statistics taken directly from the administrations of the Trans-Baikal Territory cities and from Rosstat (the Russian Federal State Statistics Service

Natural Increase/Decline and Positive/Negative Migration Balance

Table 3 $(+) /(-)$ (people)

\begin{tabular}{|l|c|c|c|c|c|c|c|c|c|c|}
\hline \multirow{2}{*}{ City } & \multicolumn{9}{|c|}{ Natural Increase (+)/Decline (-) } & \multicolumn{3}{c|}{ Positive (+)/Negative (-) Migration Balance } \\
\cline { 2 - 12 } & 1995 & 2000 & 2005 & 2010 & 2015 & 1995 & 2000 & 2005 & 2010 & 2015 \\
\hline Chita & -974 & -1297 & -378 & +1413 & +1457 & 1409 & -2050 & -1875 & +1060 & +2232 \\
\hline $\begin{array}{l}\text { Petrovsk- } \\
\text { Zabaykalsky }\end{array}$ & -189 & -210 & -281 & -179 & -83 & 84 & -98 & -87 & -167 & -259 \\
\hline Borzya & -78 & -50 & -102 & +161 & +177 & 109 & 33 & -225 & -641 & -589 \\
\hline Baley & -89 & -214 & -210 & -119 & -63 & -395 & -283 & -64 & -132 & -284 \\
\hline Nerchinsk & -21 & -19 & -142 & +50 & +57 & 12 & -259 & -71 & -29 & +1 \\
\hline Sretensk & -36 & -35 & -63 & -27 & +9 & 11 & -82 & 40 & +10 & -6 \\
\hline Krasnokamensk & 125 & 46 & -42 & +168 & +56 & -1609 & 187 & -121 & +374 & -904 \\
\hline Shilka & -60 & -91 & -162 & -4 & -6 & -112 & -63 & 9 & +10 & -8 \\
\hline Mogocha & -134 & -148 & -133 & -4 & +6 & - & -149 & -127 & -121 & -63 \\
\hline Khilok & -80 & -114 & -109 & -15 & +5 & -9 & -18 & 49 & -80 & -120 \\
\hline
\end{tabular}

Source: Own research based on the data of the statistics taken directly from the administrations of the Trans-Baikal Territory cities and Rosstat 
The highest migration loss was observed in Krasnokamensk, Borzya, Baley, and PetrovskZabaykalsky. In 2010, the migration loss exceeded the natural increase only in Krasnokamensk, while in 2015 - only in Chita. The migration outflow exceeds the natural increase only in Borzya (both in 2010 and in 2015). The migration outflow exceeds the natural decrease in Baley (both in 2010 and in 2015). In Nerchinsk, the natural increase is low, as well as the migration loss. In Shilka, both migration loss and natural population decline are low. Mogocha and Khilok are characterized by an extremely low natural increase at sufficiently high migration loss. The population of the territory is migrating to the centre (Chita) and moving outside the boundaries of the region. The employable population of Chita is also migrating to other regions, but the positive migration balance is mainly reached by the migrants from the $\mathrm{CIS}$ and China.

Thus, according to Tsykov et al. (2015), the largest proportions of population move for permanent residency to the Republic of Buryatia $-16.6 \%$, to the Irkutsk Region $-11.4 \%$, to the Novosibirsk Region $-7.2 \%$, to the Krasnodar Territory $-6.3 \%$, to Saint-Petersburg $-5.0 \%$, and to the Khabarovsk Territory $-4.5 \%$. The major portion of people shifting their place of residence consists of employable population ( $77.7 \%$ of arriving people and $75.8 \%$ of leaving people).

\section{Social and economic conditions}

Currently, an economic downfall is observed in the cities of the territory (Table 4).

Table 4

Shipment of own-produced goods, performance of work and rendering of services by own resources in the manufacturing industry (in actual prices, thousand rubles)

\begin{tabular}{|l|c|c|c|}
\hline \multirow{2}{*}{ City } & \multicolumn{3}{c|}{ Manufacturing industry } \\
\cline { 2 - 4 } & 2005 & 2010 & 2015 \\
\hline Chita & 2276408 & 5891300 & 5946047 \\
\hline Petrovsk-Zabaykalsky & 6927 & 4683 & - \\
\hline Borzya & 11145 & 384500 & 349900 \\
\hline Baley & 13905 & 4792 & - \\
\hline Nerchinsk & 4010 & 287100 & 195500 \\
\hline Sretensk & 7739 & 7647 & 1855 \\
\hline Krasnokamensk & 173970 & 67299 & - \\
\hline Shilka & 18059 & 34205 & 7700 \\
\hline Mogocha & 7666 & 34554 & 10028 \\
\hline Khilok & 3186 & 2727 & 3210 \\
\hline
\end{tabular}

"According to Chita by Numbers. Statistical Book (2015).

Source: Own research based on the data of the State Statistics Service for the Trans-Baikal Territory and Rosstat.

The share of small towns in the manufacturing activities of the territory from 2010 to 2015 reduced from $7 \%$ to $2.7 \%$. The majority of small cities are socioeconomically underdeveloped; the problems of single-industry cities are associated with the condition of city-forming enterprises. Thus, Baley, in which the "BaleyZoloto" industrial complex (one of the leading enterprises of the gold mining industry of the country) has been operating since 1929, was a large industrial centre. In 1990s, the primary production of the industrial complex was suspended. The mining activity of this period resulted in the critical environmental deterioration within the territory of the city (Chechel 2004). It can be noted that in cities with a previously developed mining industry with the termination of the industry, the problems are especially 
aggravated. An example of this is the city of Baley.

Only Nerchinsk was less influenced by the crisis in all branches of the economy (Bulayev and Baranova 2015). The city of Nerchinsk has not lost its centrality in the transport-settling structure and in the traditional flows of inter-settlement communications. Its cultural heritage, expressed in the objects of architecture and historical events, witnessing historical and political centrality is still valuable (Semibratova 2016).

Currently, in Nerchinsk food-manufacturing is the main activity. In the beginning of 2000s, a meat-processing plant, a bread production plant, a liqueur and spirits producing plant and a milk processing factory operated in the city. In the Soviet period, the production enterprises, as a rule, had a well-developed infrastructure and a high production output. At present, the output of Makner LLC, a milk-processing enterprise for the production of milk and fermented milk products, is considerably lower.

In Mogocha, Khilok and Shilka employment in the railway service is predominant. However, in the beginning of 2000s, employment at the railway reduced by several thousands of workers. The employment in the agricultural sector of cities is also in decline - only several hundreds of people work there currently (Bulayev and Baranova 2015). Thus, in almost all cities, there is a decrease in the employment rate (Table 5), which is due to a decrease in the working-age population and it is a consequence of demographic processes.

Table 5

Average number of employees of organizations (without external part-time workers) I Average annual number of employees in the economy (people)

\begin{tabular}{|l|c|c|c|c|c|}
\hline \multirow{2}{*}{ City } & \multicolumn{5}{c|}{ Years } \\
\cline { 2 - 6 } & $1995^{*}$ & $2000^{*}$ & $2005^{*}$ & $2010^{* *}$ & $2015^{* *}$ \\
\hline Chita & 131000 & 114706 & 134263 & 98700 & 96600 \\
\hline Petrovsk-Zabaykalsky & 8100 & 8333 & 4822 & 6500 & - \\
\hline Borzya & 14800 & 10756 & 4974 & 10300 & 7807 \\
\hline Baley & 6900 & 3785 & 2964 & 3774 & 3686 \\
\hline Nerchinsk & 5000 & 3655 & 3016 & - & 4010 \\
\hline Sretensk & 2600 & 2446 & 2558 & 1518 & 2190 \\
\hline Krasnokamensk & 30400 & 22614 & 21751 & 26470 & 25552 \\
\hline Shilka & 7600 & 6534 & 4557 & 4100 & 5613 \\
\hline Mogocha & 5700 & 3028 & 2189 & 6775 & - \\
\hline Khilok & 8200 & 5390 & 2842 & 5959 & 4291 \\
\hline
\end{tabular}

*1995, 2000, 2005 - given the average number of employees of organizations; Source: Rosstat

** 2010,2015 - the average annual number of the employed in the economy; Source: the Urban Development Programs.

The incomes of the city budget are formed at the expense of tax and non-tax revenues, which form their own income, as well as gratuitous receipts (funds of the regional and federal budgets). The main source of tax revenues in the city budget is the personal income tax. In recent years, in the city budgets, the expenditures exceed the revenues (or the surplus is very small) (Table 6).

The city can use its own revenues at its own discretion and they are usually spent in the social sphere. If new enterprises do not appear, first of all, in industry, the wages of those employed in the economy will not grow, and it is unlikely that the city's own revenues will increase (Gurova and Zadorozhny 2008). 
Olga GUROVA

Surplus, deficit (-) of the city budget (thousand rubles)

Table 6

\begin{tabular}{|l|c|c|c|}
\hline \multirow{2}{*}{ City } & \multicolumn{3}{c|}{ Years } \\
\cline { 2 - 4 } & $2006^{*}$ & $2010^{\star *}$ & $2015^{\text {***}}$ \\
\hline Chita & 126987.2 & -273398.6 & -110551.8 \\
\hline Petrovsk-Zabaykalsky & -25686 & 1781.6 & 564.5 \\
\hline Borzya & 291.7 & -4816 & -5788.4 \\
\hline Baley & -11792.2 & -4569 & -10103.2 \\
\hline Nerchinsk & 2162 & -3237 & 3741.0 \\
\hline Sretensk & 194 & 331.3 & 4063.2 \\
\hline Krasnokamensk & 4648.7 & 2581.6 & 16967.3 \\
\hline Shilka & 558 & -14076 & -1218.4 \\
\hline Mogocha & 548 & -8013.1 & -28314.4 \\
\hline Khilok & 127.2 & 228.5 & -11581 \\
\hline
\end{tabular}

Source: *http://chita.gks.ru ; **Execution of the local budget of the municipal entities of the Trans-Baikal Territory in 2010 (2011); ${ }^{* \star *}$ Budgets of municipal entities of the Trans-Baikal Territory in 2015 (2016).

Such housing conditions of population as parameters of their living area, the urban amenities (comfort) of the housing stock play an important role in the social and domestic infrastructure. Normal housing conditions are of great importance for human life and activities, and they also represent a considerable share of the social standard of living. The commissioning of houses increasing the social standard of living allows reducing the migration of the working population. The examination of the housing stock in cities showed that the area of the housing stock in Chita increased by 756.6 th. $\mathrm{m}^{2}$ from 2010 to 2015 . Within this period, $59090 \mathrm{~m}^{2}$ of the total area was commissioned. The living stock of other cities has not considerably grown; it is commissioned by individual builders. The active construction of houses with amenities in the different districts of Chita is differed by the number of storeys. Thus, in the Central district predominantly multi-storey houses are constructed (residential buildings of 9-10 storeys); in other districts, mid-rise and low-rise houses are erected. The highest percentage of provision of urban amenities in the housing stock is in Chita (73.8\% in average), Krasnokamensk and in Nerchinsk. In other cities, this percentage amounts to $50 \%$ and lower. Baley (former gold mining centre) shows the lowest level of provision of urban amenities; no hot water supply is provided in the town. The level of provision of liquefied gas is low: $31.3 \%$ in Chita, $17.2 \%$ in Petrovsk-Zabaykalsky, $26 \%$ in Borzya, and $19.1 \%$ in Baley. Housing and public utilities suffer serious problems, such as high deterioration of in-house networks and equipment, lack of highly-qualified specialists, including keepers of housing stock.

\section{Discussion}

As a result of the analysis of the problems of cities functioning unfavourable tendencies of demographic development were revealed. The processes of the natural and migratory movement of the population of the cities have an exceptionally important significance for the reproduction of the population. Currently, migration cannot compensate for the natural decline in population, because a negative migration balance is observed in all cities of the territory, except the administrative centre. The reasons for the outflow of the employable population out of small cities of the territory are: underdeveloped infrastructure, severe climate, lack of prospects (personnel cuts at reorganization of enterprises, low wages) and the general economic decline in the country. 
At present, the small towns of the territory perform residential, transport, administrative and organizational functions for the surrounding rural areas, but they lose their industrial function. Chita as a regional centre and a large city concentrates the population, the residential construction and the main volume of retail sales. The larger the city, the more developed its economy and infrastructure, the more stable the situation.

The discovered general trend of decline in the population of the cities of the territory for some of the cities is long-term. Thus, the dynamics of social and economic development in the cities of the territory shows the economic downfall in manufacturing (one of the basic economic sectors). The urgent problems of small cities are: the outdated infrastructure (water pipeline, sewerage, roads) and the undeveloped public amenities in residential areas, which also contributes to the outflow of the population.

The noted trends of demographic, social and economic development typical for the cities of the Trans-Baikal Territory allow for assuming that the decline in population will further determine the course of their development which is facilitated by a reduction in the measures to strengthen the economy. This is particularly the case for small towns. These phenomena indicate a crisis situation. In general, the Trans-Baikal Territory belongs to the depressive regions. The closure of enterprises and the decline in production in the 1990s led to a reduction in employment, increased unemployment and a decrease in household incomes, which led to the negative demographic and economic processes that are currently observed. In the cities of the region, the natural decline of the population is intensified by the impact of the migration outflow. In this connection, measures should be taken to overcome the negative trends and to improve the situation in the economy - the creation of new jobs and social protection measures for the population.

Cities are considered as part of the system of resettlement of municipal districts, so their development should take into account the expansion and strengthening of ties with the neighbouring settlements. All cities of the territory have similar problems to different extents. The majority of towns are located outside the influence area of the territory centre (located at a distance of hundreds of kilometres); this holds down the establishment of connections with the centre and it is an external factor limiting their development. The transport function of cities is of special importance. The availability of railway stations in cities is their competitive advantage, as it provides employment to the population.

\section{Conclusions}

The processes shown in this paper indicate the "shrinkage" of the social and economic sphere of the cities of the region, the territorial consequence of which is the "depopulation" of the territory. In the existing concept of "compression of space", Ridevsky (2010) singled out three models in the perception of geographers: the implosion of space, the polarization of space and the reduction of economic oecumene. The latter is a process associated with the depopulation of the territory and a decrease in the intensity of its economic use. Implosion is understood as a communicative contraction associated with the development of means of transport and communication, while polarization as a process of concentration of socio-economic resources and phenomena in large urban centres. The theory of representations about the centers and periphery of the socio-economic development of the territory is connected with polarization. These models are manifested in the Trans-Baikal Territory (including its cities), being characterized by a decrease in population and intensity of economic use.

When considering the prospects of cities with a single-industry (Baley, Krasnokamensk), the population size is very important. The closure of production generates unemployment and social problems for the vital activity of the population in small settlements in the case of a waste deposit and a high migration outflow is most likely awaited by the prospect of their extinction or 
loss of the status of the city. Large-sized single-industry cities, in which the process of narrowly specialized economy covers a large number of the population, have a high probability of social explosions and difficulties in the economic instability of their city-forming enterprises. The development of alternative industries (the diversification of the economy through the implementation of projects in the economy, and non-contiguous activities of the city-forming enterprise) is the most difficult and important point in solving the problems of single-industry towns (Gurova 2015).

To overcome the crisis phenomena in the economy, it is necessary to take into account the local characteristics of each city of the region: natural resources, economic resources, and the study of the possibilities of the city's investment attractiveness. For the large settlements, the likelihood of attracting federal financial support is higher. To date, the implementation of investment projects (involving investment) is planned only in Krasnokamensk, in which the construction of new plants involves the creation of new jobs. As previously emphasized (Animitsa et al. 2010), it is necessary to stop the reduction in production volumes by investments, but they should be sent not only to the reconstruction of enterprises, but also to industries that meet the current needs of the population: processing of crop and livestock products; individual tailoring of clothes and shoes; production of building materials from local raw materials (wood, stone, sand); various services, including recreational, tourist, information. For small towns, this form of development of economic activity as a small business is more real and therefore especially significant (Marshalova and Novoselov 2004). However, in small towns the shortage of local budget funds does not allow to fully implement the financial support for small businesses.

The further development of the manufacturing industry through expanding the production and the sales of products, the creation of conditions for business growth, and improving the living conditions of the population are measures to stabilize the situation in the cities of the TransBaikal Territory and other regions. However, the experience of the Trans-Baikal region shows that the problems of shrinking cities cannot be quickly resolved.

In future city studies, when understanding the motivations of population migration, it is possible to study the ways of attracting the city for the local residents through sociological surveys. But this is a topic for a separate study.

\section{Acknowledgements}

The paper was prepared within the framework of Project XI.174.1.8 according to Siberian Branch Russian Academy of Sciences Programme of Basic Scientific Research for 2017-2020.

\section{References}

ANIMITSA E. G., BOCHKO V. S., PESHINA E. V., ANIMITSA P. E. (2010), Conceptual approaches to developing a strategy for the development of a single-industry cities, Izd-vo UrGEU, Ekaterinburg.

ANTONOV E. V., DENISOV E. A., EFREMOVA V. A., FADDEEV A. M. (2014), Modern problems of development of decreasing cities in the northeast of the Komi Republic, Moscow University Bulletin. Series 5. Geography 2, 55-60.

AVILA DE SOUSA S., COTTINEAU C., DIETERSDORFER L., FERNANDEZ AGUEDA B., GONUL D., HOEMKE M., JAROSZEWSKA E., LELLA I., MYKHNENKO V., PRADA TRIGO J., SCHMITZ S., VOLKMANN A., WIECHMANN T., WOLFF M. (2011), Mapping Urban Shrinkage in Europe. Final Report, EU COST Action: TU0803, Retrieved from: www.shrinkingcities.eu.

BAŃSKI J., CZAPIEWSKI K., GÓRCZYŃSKA M. (2016), Impact of the locations of 
small towns in Mazovia (Poland) on their socio-economic structure and on their role in relation to the neighboring rural areas, Journal of Urban and Regional Analysis 8 (2), 117-131.

BULAYEV V. M., KOVALYOVA N. M. (2004), Territorial aspects of social health of population (Methodology. Characteristics. Practice), Publishing House of SB RAS Buryatiya Research Centre, Ulan-Ude.

BULAYEV V. M., BARANOVA A. A. (2015), Essays on social and demographic conditions in Russia in the beginning of XXI Century. Section IX "Peculiarities of the TransBaikal Territory", Trans-Baikal State University, Chita.

CHECHEL A. P. (2004), Baley, Encyclopedia of Transbaikalia: Chita region: in 4 volumes. Volume II. A-3., Nauka, Novosibirsk.

CHITA REGIONAL COMMITTEE ON STATISTICS (1991), Age and Gender Composition of Population of Chita Region as of 1.01.1990-1991, Chita.

CHITA REGIONAL COMMITTEE ON STATISTICS (2001), Social and Economic Performance of Municipal Districts and Urban Districts of the Trans-Baikal Territory, Chita. COUCH C., COCKS M. (2011), Underrated localism in urban regeneration: The case of Liverpool, a shrinking city, Journal of Urban Regeneration \& Renewal 4 (3), 279-292. EFREMOVA V. A. (2015), Russian and Foreign Experience of Study of Cities Losing Population: Subject Matters, Methods and Research Centres, Regional Studies 3 (49), 86-98. GATYPOVA N. V, BOLTOVSKAYA L. A. (2006), Petrovsk-Zabaikalsky Metallurgical Plant, Encyclopedia of Transbaikalia. Volume 3. I-R., "Science", Novosibirsk, pp. 432-433. GLADUN G. A. (2006), Mogocha, Encyclopedia of Transbaikalia. Volume 3. I-R. "Science", Novosibirsk, pp. 271-272.

GROßMANN K., BONTJE M., HAASE A., MYKHNENKO V. (2013), Shrinking cities: Notes for the further research agenda, Cities 35, 221-225.

GUNKO M. S. (2014), Small cities of the Central part of European Russia: the state and role in the organization of space, Izvestiya of the Russian Academy of Sciences. Series geographic 2, 43-52.

GUROVA O. N. (2015), Mono-specialized urban settlements of Trans-Baikal Territory: typology and problems of socio-economic development, Scientific bulletins of Belgorod State University. Series of Natural Sciences 3 (30), 191-198.

GUROVA O. N., ZADOROZHNY V. F. (2008), Problems of depressive territories (on the example of the urban settlement "City of Baley" of the Transbaikalian Territory), Social geography of the regions of Russia and adjacent territories: fundamental and applied research, V. B. Sochava Institute of Geography SB RAS Publisher, Irkutsk, pp. 98-101. HERRMANN D. L., SCHWARZ K., SHUSTER W. D., BERLAND A., CHAFFIN B. C., GARMESTANI A. S., HOPTON M. E. (2016), Ecology for the Shrinking City (JA), BioScience 66 (11), 965-973.

HOLLANDER J. B. (2011), Can a City Successfully Shrink? Evidence from Survey Data on Neighborhood Quality, Urban Affairs Review 47 (1), 129-141.

KARACHURINA L. B, MKRTCHYAN N. V. (2010), The dynamics of the population of municipalities of the Russian Federation as a reflection of the centro-peripheral concept of spatial development (1989-2002), Regional Studies 3, 69-83.

KONSTANTINOVA N. N. (2002), Transbaikalia in XVII-XVIII Centuries. Russian Migration to the East, Encyclopaedia of Transbaikalia: Chita Region. Volume 1. Analytical Review, «Nauka», Novosibirsk, pp. 149.

KONSTANTINOVA T. A. (2002), Transbaikalia in XIX Century and in the Beginning of XX Century. Trade. Transport Routes. Urban Growth, Encyclopaedia of Transbaikalia: Chita Region. Volume 1. Analytical Review, «Nauka», Novosibirsk, pp. 166.

MARSHALOVA A. S, NOVOSELOV A. S. (2004), Problems of formation of financial and investment resources of small towns of the Novosibirsk Region, Region: Economics and Sociology 3, 147-157.

MEDVEDEVA I. A. (2004), Tendencies and Strategy of Social and Economic Development of Small and Medium-Sized Cities of a Region (by the Example of the Perm Region and Komi-Permyak Autonomous Area), PhD. Thesis in Economic Science, 
Ekaterinburg.

PALLAGST K., ABER J., AUDIRAC I., CUNNINGHAM SABOT E., FOL S., MARTINEZFERNANDEZ C., MORAES S., MULLIGAN H., VARGAS-HERNANDEZ J., WIECHMANN T., WU T., RICH J. (2009), The Future of Shrinking Cities: Problems, Patterns and Strategies of Urban Transformation in a Global Context, UC Berkeley IURD Monograph Series, Berkeley. PALLAGST K., WIECHMANN T., MARTINEZ-FERNANDEZ C. (eds.) (2014), Shrinking cities: international perspectives and policy implications, Routledge, New York. PERTSIK E. N. (2009), Geourbanistika: Geografiya Mirovoy Urbanizatsii (Geourbanistics: Geography of the World Urbanization), Publishing Center "Academy", Moscow.

PREOBRAZHENSKII V. S. (1965), Predbaikal'e i Zabaikal'e (Cisbaikalia and Transbaikalia), Nauka, Moscow.

RICHARDSON H. W., NAM C. W. (eds.) (2014), Shrinking Cities: A Global Perspective, Routledge, New York.

RIDEVSKY G. V. (2010), Three models of space compression and regionalization as a process of squeezing space at the intra-country level, Compression of the socio-economic space: new in the theory of regional development and the practice of its state regulation, Eslan, Moscow, pp. 49-59.

RYKOV P. V. (2010), Socio-demographic transformation of the cities of the Priangarie under the conditions of transitional period, V. B. Sochava Institute of Geography SB RAS Publisher, Irkutsk.

SAVOSKUL M. S., MOZGUNOV N. A., PIVOVAR G. A. (2014), Social-economic transformation of small towns of the non-Chernozem region (case study of the Kaluga oblast), Moscow University Bulletin. Series 5. Geography 2, 62-67.

SCHETT S. (2011), An Analysis of Shrinking Cities, Urban Ecology WS 2011/12, Universität Innsbruck, Retrieved from: www.ess.co.at.

SEMIBRATOVA I. A. (2016), Transbaikalian cities of Nerchinsk and Chita: a reflection of dialectics of capital positions in modern transport and settlement structures of the border region, Humanitarian vector 11 (1), 133-142.

SOLODOVA N. B. (2004), Borzya, Encyclopedia of Transbaikalia: Chita Region: in 4 volumes. V. II. A-3, Nauka, Novosibirsk, pp. 141.

TSYKOV R. A., SHAMSUTDINOVA A. R., SCHEGLOVA S. A. (2015), The problem of migration Zabaikalsky Edge, Economic Bulletin of Trans-Baikal State University 10, 1-9.

WIECHMANN T., PALLAGST K. M. (2012), Urban shrinkage in Germany and the USA: A Comparison of Transformation Patterns and Local Strategies, International Journal of Urban and Regional Research 36 (2), 261-280.

VOROBYEV V. V. (1975), Formation of population of Eastern Siberia (Geographic Peculiarities and Problems), Nauka, Novosibirsk.

Initial submission: 22.06.2017

Revised submission: 29.11.2017

Final acceptance: 15.12.2017

Correspondence: Institute of Natural Resources, Ecology and Cryology, Siberian Branch of the Russian Academy of Sciences, PO Box No. 1032, 16-a, Nedorezova Str., Chita, the Trans-Baikal Territory, 672002, Russia

Email: lesg@bk.ru 
